\title{
UPAYA PENINGKATAN KUALITAS TANAH DI DESA SUKAMANAH DAN DESA NANGGERANG KECAMATAN CIGALONTANG KABUPATEN TASIKMALAYA JAWA BARAT MELALUI SOSIALISASI PUPUK HAYATI, PUPUK ORGANIK DAN OLAH TANAH KONSERVASI
}

\author{
Herdiyantoro, D. dan Setiawan, A. \\ Fakultas Pertanian Universitas Padjadjaran \\ E-mail: herdiyantoro@yahoo.com
}

\begin{abstract}
ABSTRAK
Pemakaian pupuk anorganik dalam jumlah berlebihan dan pengolahan tanah secara intensif dapat merusak kualitas tanah. Alternatif yang dapat digunakan untuk mengurangi dampak penggunaan pupuk anorganik dan pengolahan tanah intensif adalah dengan pupuk hayati dan pupuk organik serta olah tanah konservasi. Tujuan dari kegiatan KKNM-PPMD Integratif dengan judul Upaya Peningkatan Kualitas Tanah di Desa Sukamanah dan Desa Nanggerang Kecamatan Cigalontang Kabupaten Tasikmalaya Jawa Barat Melalui Sosialisasi Pupuk Hayati, Pupuk Organik dan Olah Tanah Konservasi adalah meningkatkan pengetahuan masyarakat tentang manfaat penggunaan pupuk hayati dan pupuk organik serta pentingnya penerapan olah tanah konservasi untuk menjaga kelestarian tanah. Kegiatan KKNM-PPMD Integratif dilaksanakan dari tanggal 7 Januari 2014 sampai dengan tanggal 6 Februari 2014. Pengenalan pupuk hayati, pupuk organik dan olah tanah konservasi dilakukan melalui pertemuan dan diskusi dengan masyarakat Desa Sukamanah dan Desa Nanggerang serta demonstrasi plot pembuatan kompos dari jerami padi. Peningkatan pengetahuan masyarakat dianalisis berdasarkan hasil ujian sebelum mengikuti kegiatan pre test dan setelah mengikuti kegiatan post test. Data dianalisis menggunakan Uji t Dua Sampel Berpasangan (Paired Sample t Test) pada taraf 5\%. Hasil kegiatan menunjukkan bahwa terjadi peningkatan pengetahuan masyarakat secara nyata khususnya petani di Desa Sukamanah tentang pupuk hayati, pupuk organik dan olah tanah konservasi.
\end{abstract}

Kata kunci: Pupuk anorganik, pupuk hayati, pupuk organik, olah tanah konservasi, Desa Sukamanah, Desa Nanggerang.

\section{ABSTRACT}

The using of the inorganic fertilizer in excessive quantities and intensive soil tilling can damage soil quality. Alternatives that can be used to reduce the impact of the both methodare by using the biofertilizer, organic fertilizers and conservation soil tillage. The purpose of KKNM-PPMD Integratif entitled Efforts of Increase Soil Quality at Desa Sukamanah and Desa Nanggerang Kecamatan Cigalontang Kabupaten Tasikmalaya West Java through Biofertilizer, Organic Fertilizer and Conservation Soil Tillage. Socialization was done to increase knowledge of the society about utilizing biofertilizer, organic fertilizer and conservation soil tillage to keep soil sustainability. KKNM-PPMD Integratif activities took place from January $7^{\text {th }}$ until February $6^{\text {th }}$, 2014. The activity was done by companionship and discussion with Desa Sukamanah and Desa Nanggerang society and plot demonstration making compost with rice straw material. Society knowledge increase was analyzed based pre test before activity and post test after activity.
Data was analyzed using Paired Sample $t$ Test Analyzed at 5\% level. The result of activity showed us there was increase knowledge significantly about biofertilizer, organic fertilizer and conservation soil tillage at Desa Sukamanah society notably.

Key words: Inorganic fertilizer, biofertilizer, organic fertilizer, conservation soil tillage, Desa Sukamanah, Desa Nanggerang.

\section{PENDAHULUAN}

Dominasi aktivitas ekonomi masyarakat di Desa Sukamanah dan Desa Nanggerang Kecamatan Cigalontang Kabupaten Tasikmalaya adalah petani. Mayoritas penghasilan penduduk berasal dari hasilhasil pertanian sehingga produksi unggulan desa adalah hasil bumi seperti beras. Sektor pertanian ini sangat penting bagi kemakmuran desa. Namun, sebagian besar dari mereka adalah buruh tani, bukan pemiliknya.

Petani lebih memperhatikan kepentingan sesaat daripada kepentingan jangka panjang. Pemakaian pupuk anorganik dalam jumlah berlebihan di atas takaran rekomendasi selama ini sudah mulai memberikan dampak lingkungan yang negatif seperti menurunnya kandungan bahan organik tanah, rentannya tanah terhadap erosi, menurunnya permeabilitas tanah, menurunnya populasi mikroba tanah, dan sebagainya. Akibat dari kemiskinan petani, mereka lebih mengutamakan hasil panen yang tinggi setiap musim tanam daripada keletarian sumber daya lahan dan keberlanjutan produksi untuk kepentingan generasi berikutnya.

Salah satu solusi untuk mengatasi hal tersebut adalah mensubsitusi atau mengkomplementer pemakaian pupuk anorganik dengan pupuk hayati atau pupuk organik serta penerapan olah tanah konservasi. Pupuk hayati adalah pupuk yang berisi mikroorganisme hidup yang berfungsi untuk membantu penyediaan unsur hara bagi tanaman. Berbagai jenis pupuk hayati telah banyak beredar di pasaran. Jerami padi yang melimpah di Desa Sukamanah dan Desa Nanggerang merupakan bahan baku kompos yang dapat dijadikan potensi sebagai pensubsitusi atau pengkomplementer pemakaian pupuk anorganik yang selama ini digunakan oleh petani dalam jumlah yang berlebih yang dampaknya dapat menurunkan kualitas tanah. Jerami padi tersebut dapat diolah melalui proses pengomposan untuk dijadikan pupuk organik. Dengan menggunakan sistem pengolahan tanah yang intensif, pada mulanya petani mendapatkan hasil panen yang tinggi. Namun, karena tanah terus-menerus diolah akibatnya tanah mengalami penurunan produktivitas. Tanah yang diolah berlebihan tanpa tindakan konservasi akan menjadi lebih cepat kering, lebih halus (powdery), berstruktur buruk, dan berkadar bahan organik tanah rendah. Olah tanah 
konservasi (OTK) adalah suatu cara pengolahan tanah yang bertujuan untuk menyiapakan lahan agar tanaman dapat tumbuh dan berproduksi optimum, namum tetap memperhatikan aspek konservasi tanah dan air. Sistem OTK dicirikan oleh berkurangnya pembongkaran/ pembalikan tanah, penggunaan sisa tanaman sebagai mulsa, dan kadang-kadang disertai penggunaan herbisida untuk menekan pertumbuhan gulma atau tanaman pengganggu lainnya.

Maksud dan tujuan dari program pengabdian masyarakat ini adalah: (i) meningkatkan pengetahuan masyarakat tentang pupuk hayati, pupuk organik dan olah tanah konservasi, (ii) agar para petani dapat mengetahui keuntungan penggunaan pupuk hayati, pupuk organik dan olah tanah konservasi yang dapat meningkatkan kualitas tanah dan (iii) meningkatkan rasa kebersamaan antar sesama warga di Desa Sukamanah dan Desa Nanggerang Kecamatan Cigalontang Kabupaten Tasikmalaya Jawa Barat dalam menjaga kelestarian lahan pertanian.

\section{SUMBER INSPIRASI}

Kualitas tanah seringkali dinyatakan sebagai kemampuan yang dimiliki oleh tanah secara alamiah untuk memproduksi hasil yang memadai dari tanaman berkualitas tinggi serta melindungi kesehatan manusia dan hewan tanpa merusak sumberdaya alam (Doran \& Parkin, 1994). Lebih lanjut Doran \& Parkin (1994) memberikan batasan kualitas tanah adalah kapasitas suatu tanah untuk berfungsi dalam batas-batas ekosistem untuk melestarikan produktivitas biologi, memelihara kualitas lingkungan, serta meningkatkan kesehatan tanaman dan hewan. Indikator kualitas tanah adalah sifat, karakteristik atau proses fisika, kimia dan biologi tanah yang dapat menggambarkan kondisi tanah (SQI, 2001).

Petani lebih memperhatikan kepentingan sesaat daripada kepentingan jangka panjang. Pemakaian pupuk anorganik terutama dalam jumlah berlebihan di atas takaran rekomendasi selama ini sudah mulai memberikan dampak lingkungan yang negatif seperti menurunnya kandungan bahan organik tanah, rentannya tanah terhadap erosi, menurunnya permeabilitas tanah, menurunnya populasi mikroba tanah dan sebagainya. Akibat dari kemiskinan petani, mereka lebih mengutamakan hasil panen yang tinggi setiap musim tanam daripada kelestarian sumber daya lahan dan keberlanjutan produksi untuk kepentingan generasi berikutnya.

Kenyataan menunjukkan bahwa peningkatan hasil tanaman biji-bijian, penanaman lahan secara ekstensif, serta penggunaan pupuk kimia dan pestisida untuk pertumbuhan tanaman telah meningkatkan produksi pertanian dua sampai tiga kali lipat dan mengefisienkan penggunaan tenaga kerja. Sistem pertanian semacam itu ternyata juga meningkatkan kehilangan bahan organik tanah, terjadinya erosi serta kontaminasi air tanah dan air permukaan di berbagai daerah di dunia. Tidak heran jika kemudian timbul motivasi dari pakar pertanian dan lingkungan untuk beralih mengelola sistem pertanian dengan input yang intensif (input-intensive management) untuk mengurangi eksternal input yang banyak, yaitu suatu sistem pertanian yang umum dilakukan pada saat ini. Caranya antara lain dengan melindungi kesehatan tanah dari bahaya potensial pupuk kimia, pestisida, serta peduli terhadap perlindungan lingkungan dan sumberdaya tanah.

Tumbuhnya kesadaran akan dampak negatif penggunaan pupuk buatan dan sarana pertanian modern lainnya terhadap lingkungan pada sebagian kecil petani telah membuat mereka beralih dari pertanian konvensional ke pertanian yang ramah lingkungan. Pertanian jenis ini mengandalkan kebutuhan hara melalui masukan-masukan alami seperti pupuk hayati dan pupuk organik serta pengolahan tanah dengan kaidah konservasi.

Istilah pupuk hayati digunakan sebagai nama kolektif untuk semua kelompok fungsional mikroba tanah yang dapat berfungsi sebagai penyedia hara dalam tanah, sehingga dapat tersedia bagi tanaman. Pupuk hayati dapat didefinisikan sebagai inokulan berbahan aktif organisme hidup yang berfungsi untuk menambat hara tertentu atau memfasilitasi tersedianya hara dalam tanah bagi tanaman. Memfasilitasi tersedianya hara ini dapat berlangsung melalui peningkatan akses tanaman terhadap hara misalnya oleh cendawan mikoriza arbuskuler, pelarutan oleh mikroba pelarut fosfat, maupun perombakan oleh fungsi, aktinomiset atau cacing tanah. Penyediaan hara ini berlangsung melalui hubungan simbiotis atau nonsimbiotis. Secara simbiosis berlangsung dengan kelompok tanaman tertentu atau dengan kebanyakan tanaman sedangkan nonsimbiotis berlangsung melalui penyerapan hara hasil pelarutan oleh kelompok mikroba pelarut fosfat, dan hasil perombakan bahan organik oleh kelompok organisme perombak. Mikroorganisme dalam pupuk mikroba yang digunakan dalam bentuk inokulan dapat mengandung hanya satu strain tertentu atau monostrain tetapi dapat pula mengandung lebih dari satu strain atau multistrain. Strain-strain pada inokulan multistrain dapat berasal dari satu kelompok inokulasi silang (cross inoculation) atau lebih. Pada mulanya hanya dikenal inokulan yang hanya mengandung satu kelompok fungsional mikroba (pupuk hayati tunggal), tetapi perkembangan teknologi inokulan telah memungkinkan memproduksi inokulan yang mengandung lebih dari satu kelompok fungsional mikroba. Inokulan-inokulan komersial saat ini mengandung lebih dari suatu spesies atau lebih dari satu kelompok fungsional mikroba. Karena itu Simanungkalit dan Saraswati (1993) memperkenalkan istilah pupuk hayati majemuk untuk pertama kali bagi pupuk hayati yang mengandung lebih dari satu kelompok fungsional.

Di Indonesia pembuatan inokulan rhizobia dalam bentuk biakan murni rhizobia pada agar miring telah mulai sejak tahun 1938 tapi hanya untuk keperluan penelitian. Dalam skala komersial pembuatan inokulan rhizobia mulai di Laboratorium Mikrobiologi, Fakultas Pertanian Universitas Gadjah Mada, Yogyakarta sejak tahun 1981 untuk memenuhi keperluan petani transmigran (Jutono, 1982). Pada waktu itu inokulan diberikan kepada petani sebagai salah satu komponen dalam paket yang diberikan dalam proyek intensifikasi kedelai. Penyediaan inokulan dalam proyek ini berdasarkan pesanan pemerintah kepada produsen inokulan, yang tadinya hanya satu produsen saja menjadi tiga produsen. Inokulan tidak tersedia di pasar bebas, tetapi hanya berdasarkan pesanan. Pada periode 1983-1986, inokulan (Legin) sebanyak 68.034,67 kg telah digunakan untuk menginokulasi tanaman kedelai seluas 
453.564 ha pada 25 provinsi di Indonesia (Sebayang dan Sihombing, 1987). Pada musim tanam tahun 1997/1998, jenis inokulan lain (pupuk hayati majemuk Rhizoplus) sebanyak 41.348,75 kg digunakan untuk menginokulasi 330.790 ha kedelai di 26 provinsi (Saraswati et al., 1998)

Pupuk organik adalah nama kolektif untuk semua jenis bahan organik asal tanaman dan hewan yang dapat dirombak menjadi hara tersedia bagi tanaman. Dalam Permentan No. 2/Pert/Hk.060/2/2006, tentang pupuk organik dan pembenah tanah, dikemukakan bahwa pupuk organik adalah pupuk yang sebagian besar atau seluruhnya terdiri atas bahan organik yang berasal dari tanaman dan atau hewan yang telah melalui proses rekayasa, dapat berbentuk padat atau cair yang digunakan mensuplai bahan organik untuk memperbaiki sifat fisik, kimia, dan biologi tanah. Definisi tersebut menunjukkan bahwa pupuk organik lebih ditujukan pada kandungan C-organik atau bahan organik daripada kadar haranya. Nilai C-organik itulah yang menjadi pembeda dengan pupuk anorganik.

Sumber bahan organik dapat berupa kompos, pupuk hijau, pupuk kandang, sisa panen (jerami, brangkasan, tongkol jagung, bagas tebu, dan sabut kelapa), limbah ternak, limbah industri yang menggunakan bahan pertanian, dan limbah kota. Kompos merupakan produk pembusukan dari limbah tanaman dan hewan hasil perombakan oleh fungi, aktinomiset, dan cacing tanah. Pupuk hijau merupakan keseluruhan tanaman hijau maupun hanya bagian dari tanaman seperti sisa batang dan tunggul akar setelah bagian atas tanaman yang hijau digunakan sebagai pakan ternak. Sebagai contoh pupuk hijau ini adalah sisa-sisa tanaman, kacang-kacangan, dan tanaman paku air Azolla. Pupuk kandang merupakan kotoran ternak. Limbah ternak merupakan limbah dari rumah potong berupa tulang-tulang, darah, dan sebagainya. Limbah industri yang menggunakan bahan pertanian merupakan limbah berasal dari limbah pabrik gula, limbah pengolahan kelapa sawit, penggilingan padi, limbah bumbu masak, dan sebagainya. Limbah kota yang dapat menjadi kompos berupa sampah kota yang berasal dari tanaman, setelah dipisah dari bahan-bahan yang tidak dapat dirombak misalnya plastik, kertas, botol, dan kertas.

Dengan menggunakan sistem pengolahan tanah yang intensif, pada mulanya petani mendapatkan hasil panen yang tinggi. Namun karena tanah terusmenerus diolah akibatnya tanah mengalami penurunan produktivitas. Tanah yang diolah berlebihan tanpa tindakan konservasi akan menjadi lebih cepat kering, lebih halus (powdery), berstruktur buruk dan berkadar bahan organik tanah rendah. Pengolahan tanah dapat diartikan sebagai kegiatan manipulasi mekanik terhadap tanah (Arsyad, 2000). Tujuannya adalah untuk mencampur dan menggemburkan tanah, mengontrol tanaman pengganggu, mencampur sisa tanaman dengan tanah dan menciptakan kondisi kegemburan tanah yang baik untuk pertumbuhan akar (Gill \& Berg, 1967).

Setiap upaya pengolahan tanah menyebabkan terjadinya perubahan sifat-sifat tanah. Tingkat perubahan yang terjadi sangat ditentukan oleh jenis alat pengolah tanah yang digunakan. Penggunaan cangkul relatif tidak akan banyak menyebabkan terjadinya pemadatan pada lapisan bawah tanah. Namun karena seringnya tanah terbuka, terutama diantara 2 musim tanam, maka lebih riskan terhadap dispersi agregat, erosi dan proses iluviasi yang selanjutnya dapat memadatkan tanah (Pankhurst \& Lynch, 1993). Penggunaan alat berat akan menggemburkan tanah dan membolak-balikkan tanah sampai kedalaman $20 \mathrm{~cm}$. Namum pada waktu yang bersamaan roda traktor menyebabkan terjadinya pemadatan tanah. Beberapa penelitian menunjukkan bahwa pengolahan tanah yang berlebihan menjadi penyebab utama terjadinya kerusakan struktur tanah (Larson \& Osborne, 1982; Suwardjo et al. 1989) dan kekahatan kandungan bahan organik tanah.

Kepedulian terhadap efek negatif dari pengolahan tanah yang intensif mendorong para praktisi pertanian mencari alternatif penyiapan lahan yang lebih rasional terhadap kelestarian lingkungan hidup. Olah tanah konservasi (OTK) adalah cara penyiapan lahan yang menyisakan sisa tanaman di atas permukaan tanah sebagai mulsa dengan tujuan untuk mengurangi erosi dan penguapan air dari permukaan tanah. Utomo (1995) mendefinisikan OTK sebagai suatu cara pengolahan tanah yang bertujuan untuk menyiapakan lahan agar tanaman dapat tumbuh dan berproduksi optimum, namum tetap memperhatikan aspek konservasi tanah dan air. Sistem OTK dicirikan oleh berkurangnya pembongkaran/ pembalikan tanah, penggunaan sisa tanaman sebagai mulsa, dan kadang-kadang disertai penggunaan herbisida untuk menekan pertumbuhan gulma atau tanaman pengganggu lainnya. Beberapa cara OTK yang akhirakhir ini banyak diperkenalkan adalah tanpa olah tanah (zero tillage), olah tanah seperlunya (reduced tillage) dan olah tanah strip (strip tillage).

\section{MAKSUD DAN TUJUAN}

Kegiatan KKNM-PPMD Integratif dilaksanakan di Desa Sukamanah dan Desa Nanggerang, Kecamatan Cigalontang, Kabupaten Tasikmalaya, Jawa Barat. Waktu pelaksanaan mulai tanggal 7 Januari 2014 sampai dengan tanggal 6 Februari 2014.

Kegiatan dilaksanakan dengan metode pendidikan melalui penyuluhan mengenai pupuk hayati, pupuk organik dan olah tanah konservasi serta demontrasi plot pembuatan kompos dengan memanfaatkan bahan baku jerami padi. Pendekatan partisipatif dilakukan melalui observasi terhadap kondisi lingkungan desa dan dialog dengan masyarakat petani di Desa Sukamanah dan Desa Nanggerang Kecamatan Cigalontang Kabupaten Tasikmalaya Jawa Barat kemudian membuat perencanaan pelaksanaan sampai dengan melaksanakan demonstrasi plot yaitu pembuatan pupuk organik kompos dengan melibatkan masyarakat petani setempat. Kegiatan ini melibatkan para tokoh masyarakat, petani dan penggarap, karang taruna, dan sekolah-sekolah formal. Partisipasi masyarakat sangat diperlukan untuk menjaga keberlanjutan program dan dalam rangka menumbuhkan kepedulian berbagai pihak terkait.

Kegiatan yang dilakukan antara lain: (i) mengadakan pertemuan dengan kepala desa dan aparatur pemerintahan desa, tokoh-tokoh masyarakat dan petani serta Petugas Penyuluh Lapangan, (ii) melakukan pendekatan dengan tokoh masyarakat berasaskan kekeluargaan dan bersifat saling menguntungkan, (iii) menentukan tempat yang akan digunakan untuk mendukung pelaksanaan penyuluhan dan demonstrasi plot, (iv) melakukan penyuluhan dengan materi 
pengetahuan tentang pupuk hayati, pupuk organik dan olah tanah konservasi melalui diskusi maupun penayangan gambar-gambar secara interaktif dan, (v) melakukan demonstrasi plot pembuatan pupuk organik pada lahan yang sudah ditentukan.

Keberhasilan kegiatan Upaya Peningkatan Kualitas Tanah di Desa Sukamanah dan Desa Nanggerang Kecamatan Cigalontang Kabupaten Tasikmalaya Jawa Barat Melalui Sosialisasi Pupuk Hayati, Pupuk Organik dan Olah Tanah Konservasi dapat diukur melalui tingkat partisipasi para petani (kelompok tani) dalam mengikuti sosialisasi, baik di dalam kelas maupun praktik di lapangan. Selain itu juga, berdasarkan perubahan perilaku (pengetahuan dan sikap) dalam penatagunaan lahan berkaitan dengan sosialisasi pupuk hayati, pupuk organik dan olah tanah konservasi tanah sebagai upaya peningkatan kualitas tanah. Peserta dinilai berdasarkan kemudahan dalam memahami materi, kesesuaian materi dengan kebutuhan para petani, wiraswasta, dan pemerintah daerah. Para peserta diberikan ujian sebelum mengikuti kegiatan pre test dan setelah mengikuti kegiatan post test. Data hasil ujian digunakan sebagai indikator tingkat pemahaman para peserta terhadap materi yang diberikan. Data dianalisis menggunakan Uji t Dua Sampel Berpasangan (Paired Sample t Test) pada taraf 5\% (Pratisto, 2004).

\section{KARYA UTAMA}

Tahap pertama masyarakat dikenalkan dengan kegiatan pertanian dengan berbagai pola kegiatan dan hasil-hasilnya ataupun dampak dari kegiatan tersebut terhadap kualitas tanah akibat pemakaian pupuk anorganik secara berlebih serta pengolahan tanah secara intensif, misalnya pemakaian pupuk urea secara berlebih dapat membuat tanah menjadi padat karena urea bersifat dapat menyerap air (higroskopis).

Selanjutnya masyarakat dikenalkan dengan adanya pupuk hayati dan pupuk organik serta olah tanah konservasi dengan berbagai manfaatnya bagi produktivitas tanah dan tanaman. Misalnya pupuk hayati yang mengandung bakteri pelarut fosfat (BPF) dapat melarutkan $\mathrm{P}$ tanah yang terikat oleh $\mathrm{Al}$ atau $\mathrm{Fe}$ sehingga ketersediaan unsur P menjadi meningkat bagi tanaman. Selain itu, pemakaian pupuk organik berupa kompos tidak hanya memberikan keuntungan berupa penambahan unsur hara bagi tanaman, tetapi juga dapat memperbaiki sifat-sifat tanah lainnya seperti peningkatan muatan negatif tanah, peningkatan daya memegang air dan peningkatan stabilisasi agregat tanah. Oleh karena itu proses pembuatan kompos (berbahan dasar jerami padi) diperkenalkan dalam kegiatan penyuluhan agar masyarakat dapat mengetahui teknologi pengomposan yang dapat menghasilkan kompos dalam waktu cepat dan berkualitas tinggi.

\section{ULASAN KARYA}

Pengenalan dan pemahaman pupuk hayati, pupuk organik dan olah tanah konservasi dilakukan melalui pertemuan dan diskusi dengan masyarakat desa di Aula Balai Desa Sukamanah dan Desa Nanggerang yang masing-masing dihadiri oleh 23 orang dan 15 orang. Kelompok ini diharapkan secara bertahap dapat mengenali dan memahami materi pupuk hayati, pupuk organik dan olah tanah konservasi yang dikenalkan dan selanjutnya akan disampaikan kepada pihak keluarga atau rekan lainnya.

Pertemuan-pertemuan yang telah dilakukan berjalan secara interaktif dengan ditunjang ilustrasi visual mengenai pupuk hayati dan teknologi pembuatan kompos jerami menggunakan dekomposer sebagai pupuk organik serta olah tanah konservasi sehingga membuka peluang masyarakat untuk bertanya jawab ataupun mengeluarkan pendapat dan ide yang memungkinkan pengembangan kegiatan pertanian di masyarakat. Masyarakat secara antusias mengikuti kegiatan ini dengan diskusi dan tanya jawab. Dari hasil pertemuan-pertemuan tersebut dapat diketahui bahwa masyarakat sudah memahami pentingnya kegiatan yang disosialisasikan dan menggugah minat untuk dapat melaksanakannya. Hal ini tentunya sudah merupakan suatu kemajuan yang berarti, tetapi perlu ditindaklanjuti oleh tahapan berikutnya secara berkelanjutan. Untuk itu, melalui aparat terkait diharapkan kegiatan ini dapat ditindaklanjuti melalui kegiatankegiatan demontrasi secara langsung di masyarakat dan pembinaan ke depannya.

Pengetahuan masyarakat di Desa Sukamanah meningkat setelah mengikuti kegiatan sosialisasi. Berikut adalah hasil analisis statistika dan interpretasi data terhadap kegiatan sosialisasi yang telah dilaksanakan di Desa Sukamanah.

Tabel 1. menunjukkan bahwa rata-rata nilai ujian peserta Desa Sukamanah sebelum penyuluhan adalah 73,91 sedangkan nilai setelah penyuluhan adalah 79,13 .

Tabel 1. Hasil Analisis Statistika Rata-Rata Nilai Ujian Peserta Desa Sukamanah Sebelum dan Sesudah Mengikuti Kegiatan Sosialisasi.

\begin{tabular}{lcccc}
\hline \multicolumn{4}{c}{ Paired Samples Statistics } \\
\hline & Mean & N & $\begin{array}{c}\text { Std. } \\
\text { Deviation }\end{array}$ & $\begin{array}{c}\text { Std. } \\
\text { Error } \\
\text { Mean }\end{array}$ \\
\hline Pair 1 Nilai Ujian \\
$\begin{array}{l}\text { Sebelum } \\
\text { Penyuluhan di }\end{array}$ & 73.91 & 23 & 11.962 & 2.494 \\
$\begin{array}{l}\text { Desa Sukamanah } \\
\text { Nilai Ujian }\end{array}$ & & & & \\
$\begin{array}{l}\text { Setelah } \\
\text { Penyuluhan di } \\
\text { Desa Sukamanah }\end{array}$ & 79.13 & 23 & 11.644 & 2.428 \\
\hline
\end{tabular}

Tabel 2. menunjukkan hasil uji kekuatan hubungan antara nilai ujian sebelum penyuluhan dan sesudah penyuluhan di Desa Sukamanah. Korelasi nilai ujian sebelum penyuluhan dan sesudah penyuluhan adalah 0,580 . Dengan melihat nilai probabilitas $0,004(<0,05)$ berarti korelasi antara nilai ujian sebelum penyuluhan dan sesudah penyuluhan adalah signifikan atau erat.

Tabel 3. menunjukkan pengaruh kegiatan sosialisasi terhadap peningkatan pengetahuan masyarakat Desa Sukamanah mengenai pupuk hayati, pupuk organik dan olah tanah konservasi. Hipotesis yang diajukan adalah sebagai berikut: $\mathrm{H} 0=$ Pengetahuan masyarakat Desa Sukamanah sebelum dan sesudah penyuluhan sama; H1 = Pengetahuan masyarakat Desa Sukamanah sebelum dan sesudah penyuluhan berbeda. Tabel 4.3. menunjukkan probabilitas sebesar $0,030(<0,05)$ maka 
H0 ditolak artinya pengetahuan masyarakat Desa Sukamanah terbukti meningkat setelah mengikuti penyuluhan. Hal ini dimungkinkan karena masyarakat Desa Sukamanah khususnya petani peserta sosialisasi dapat memahami dengan baik materi penyuluhan dan demonstrasi plot mengenai pupuk hayati, pupuk organik dan olah tanah konservasi.

Tabel 2. Hasil Analisis Statistika Korelasi Nilai Ujian Peserta Desa Sukamanah Sebelum dan Sesudah Mengikuti Kegiatan Sosialisasi.

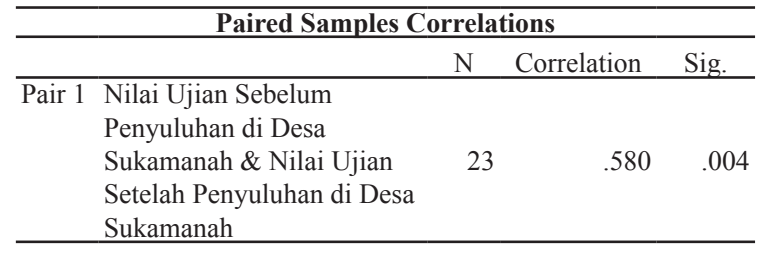

Tabel 3. Hasil Analisis Statistika Pengaruh Kegiatan Sosialisasi terhadap Peningkatan Pengetahuan Masyarakat Desa Sukamanah.

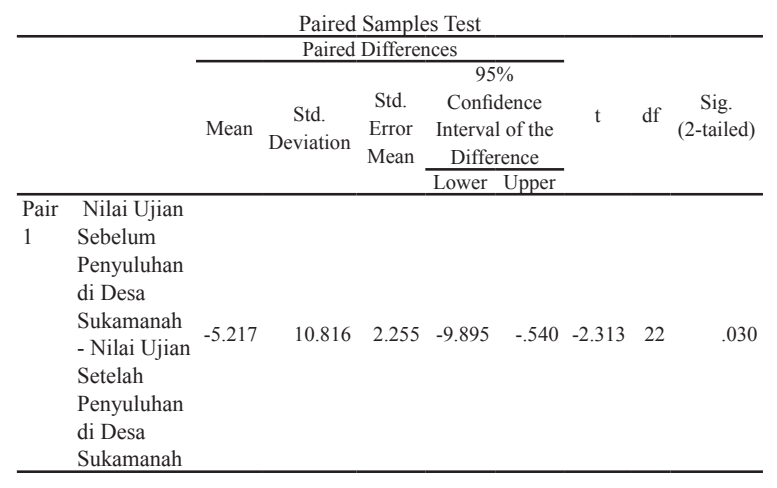

Pengetahuan masyarakat di Desa Nanggerang tidak ada peningkatan setelah mengikuti kegiatan sosialisasi. Berikut adalah hasil analisis statistika dan interpretasi data terhadap kegiatan sosialisasi yang telah dilaksanakan di Desa Nanggerang.

Tabel 4. menunjukkan bahwa rata-rata nilai ujian peserta Desa Nanggerang sebelum penyuluhan adalah 84,00 sedangkan nilai setelah penyuluhan adalah 87,33.

Tabel 4. Hasil Analisis Statistika Rata-Rata Nilai Ujian Peserta Desa Nanggerang Sebelum dan Sesudah Mengikuti Kegiatan Sosialisasi.

\begin{tabular}{|c|c|c|c|c|}
\hline & Mean & $\mathrm{N}$ & $\begin{array}{c}\text { Std. } \\
\text { Deviation }\end{array}$ & $\begin{array}{c}\text { Std. Error } \\
\text { Mean }\end{array}$ \\
\hline $\begin{array}{ll}\text { Pair } 1 & \text { Nilai Ujian } \\
& \text { Sebelum } \\
& \text { Penyuluhan } \\
& \text { di Desa } \\
\text { Nanggerang } \\
\text { Nilai Ujian } \\
\text { Setelah } \\
\text { Penyuluhan } \\
\text { di Desa } \\
\text { Nanggerang }\end{array}$ & 84.00 & 15 & 7.368 & 1.902 \\
\hline
\end{tabular}

Tabel 5. menunjukkan hasil uji kekuatan hubungan antara nilai ujian sebelum penyuluhan dan sesudah penyuluhan di Desa Nanggerang. Korelasi nilai ujian sebelum penyuluhan dan sesudah penyuluhan adalah 0,437 . Dengan melihat nilai probabilitas 0,103 $(>0,05)$ berarti korelasi antara nilai ujian sebelum penyuluhan dan sesudah penyuluhan adalah tidak signifikan atau tidak erat.

Tabel 5. Hasil Analisis Statistika Korelasi Nilai Ujian Peserta Desa Nanggerang Sebelum dan Sesudah Mengikuti Kegiatan Sosialisasi.

\begin{tabular}{|c|c|c|c|c|}
\hline \multicolumn{5}{|c|}{ Paired Samples Correlations } \\
\hline & & $\mathrm{N}$ & Correlation & Sig. \\
\hline Pair 1 & $\begin{array}{l}\text { Nilai Ujian Sebelum } \\
\text { Penyuluhan di Desa } \\
\text { Nanggerang \& } \\
\text { Nilai Ujian Setelah } \\
\text { Penyuluhan di Desa } \\
\text { Nanggerang }\end{array}$ & 15 & .437 & .103 \\
\hline
\end{tabular}

Tabel 6. menunjukkan pengaruh kegiatan sosialisasi terhadap peningkatan pengetahuan masyarakat Desa Nanggerang mengenai pupuk hayati, pupuk organik dan olah tanah konservasi. Hipotesis yang diajukan adalah sebagai berikut: $\mathrm{H0}=$ Pengetahuan masyarakat Desa Nanggerang sebelum dan sesudah penyuluhan sama; H1 = Pengetahuan masyarakat Desa Nanggerang sebelum dan sesudah penyuluhan berbeda. Tabel 4.6. menunjukkan probabilitas sebesar 0,136 (>0,05) maka $\mathrm{H} 0$ diterima artinya pengetahuan masyarakat Desa Nanggerang tidak terbukti meningkat setelah mengikuti penyuluhan. Hal ini diduga karena masyarakat Desa Nanggerang khususnya petani telah memiliki dasar pengetahuan serta menerapkan pupuk hayati, pupuk organik dan olah tanah konservasi dalam kegiatan budidaya tanaman.

Tabel 6. Hasil Analisis Statistika Pengaruh Kegiatan Sosialisasi terhadap Peningkatan Pengetahuan Masyarakat Desa Nanggerang.

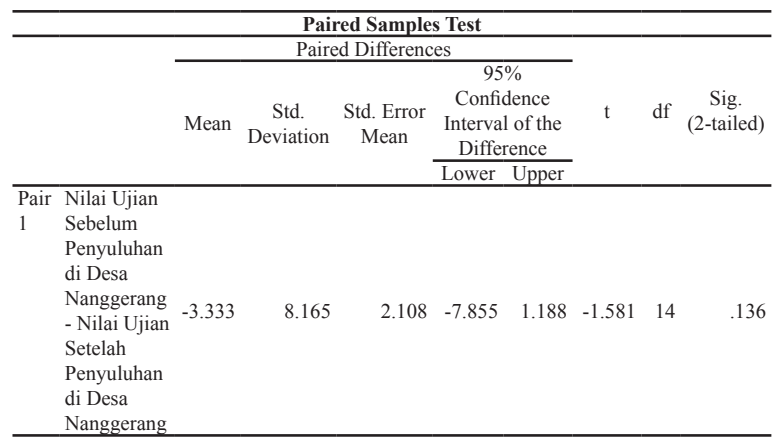

\section{DAMPAK DAN MANFAAT}

Jika dilihat dari kerangka evaluasi yang telah dibuat, hal ini telah mencapai beberapa kondisi yang dinginkan sebagai berikut: (i) adanya peningkatan pengetahuan masyarakat khususnya petani di Desa Sukamanah tentang pupuk hayati, pupuk organik dan olah tanah konservasi serta dampak pemakaian pupuk anorganik secara berlebih dan sistem pengolahan tanah yang intensif pada lahan pertanian, (ii) adanya peningkatan pengetahuan masyarakat khususnya petani di Desa Sukamanah akan keuntungan penggunaan pupuk hayati dan pupuk organik yang dapat mengurangi pemakaian penggunaan pupuk anorganik serta manfaat penerapan olah tanah konservasi, (iii) adanya peningkatan rasa kebersamaan antar sesama warga di Desa Sukamanah dan Desa Nanggerang, Kecamatan Cigalontang, Kabupaten Tasikmalaya, 
Provinsi Jawa Barat dalam menjaga kelestarian lahan pertanian dan (iv) adanya peningkatan kesadaran masyarakat bahwa bertani haruslah juga menjaga kesuburan lahan.

\section{SIMPULAN}

Kegiatan KKNM-PPMD Integratif dengan tema upaya peningkatan kualitas tanah di Desa Sukamanah dan Desa Nanggerang Kecamatan Cigalontang Kabupaten Tasikmalaya Jawa Barat melalui sosialisasi pupuk hayati, pupuk organik dan olah tanah konservasi dapat meningkatkan pengetahuan masyarakat khususnya di Desa Sukamanah tentang manfaat penggunaan pupuk hayati dan pupuk organik serta pentingnya penerapan olah tanah konservasi untuk menjaga kelestarian tanah. Pengetahuan masyarakat tentang pupuk hayati dan pupuk organik memberikan harapan baru bagi pemanfaatan sumber pupuk selain pupuk anorganik dan demonstrasi plot memberikan keterampilan pemanfaatan limbah organik seperti jerami padi menjadi pupuk organik atau kompos secara cepat dan berkualitas. Selain itu pengetahuan olah tanah konservasi memberikan kesadaran kepada masyarakat untuk mengolah tanah secara bijak sehinga kegiatan pertanian yang dilakukan masyarakat lebih bersifat lestari dan berkelanjutan.

\section{PENGHARGAAN}

Terimakasih disampaikan kepada Lembaga Penelitian dan Pengabdian Kepada Masyarakat Universitas Padjadjaran yang telah memfasilitasi pelaksanaan kegiatan pengabdian masyarakat melalui Kegiatan KKNM-PPMD Integratif di Desa Sukamanah dan Desa Nanggerang Kecamatan Cigalontang Kabupaten Tasikmalaya Jawa Barat.

Program pengabdian kepada masyarakat ini dibiayai dari DIPA Universitas Padjadjaran Tahun Anggaran 2014, sesuai dengan Surat Perjanjian Pelaksanaan Pengabdian kepada Masyarakat Nomor: 121/UN6.R/ PM/2014 Tanggal 20 Januari 2014.

\section{DAFTAR PUSTAKA}

Arsyad S. 2000. Pengawetan Tanah dan Air. Bogor: Departemen Ilmu-llmu Tanah. Fakultas Pertanian. Institut Pertanian Bogor.

Doran J.W., Parkin, T.B., Coleman D.C., Bezdicek, D.F., dan Stewart, B.A. 1994. Defining and Assessing Soil Quality, in Defining Soil Quality for a Sustainable Environment. Soil Sci. Soc. Am. (35):3-21.

Gill, W.R., Vanden Berg, G.E. 1967. Soil Dynamics in Tillage a USDA Agric. Washington DC: Handb. N. 316. U.S. Government Printing.

Jutono. 1982. The application of Rhizobium-inoculant on soybean in Indonesia. Ilmu Pert. (Agric. Sci.) 3(5): 215-222.
Larson, W.E., Osborne, G.J. 1982. Tillage Accomplishments and Potential. In Predicting Tillage Effects on Soil Physical Properties and Processes. ASA Special Publication No. 44.

Macdonald, 1989. An overview of crop inoculation. In Campbell R, Macdonald RM (Eds.). Microbial Inoculation of Crop Plants. Oxford: IRL Press.

Pankhurst, C.E., Lynch, J.M. 1993. The Role of Soil Biota in Sustainable Agriculture. Pp 3-9. In Pankhurst CE, Daube BM, Gupta VVSR, Grace PR (Eds.) Soil Biota: Management in Sustainable Farming Systems. Melbourne, Australia: CSIRO Press.

Pratisto, A. 2004. Cara Mudah Mengatasi Masalah Statistik dan Rancangan Percobaan dengan SPSS 12. Jakarta: PT. Elex Media Komputindo.

Saraswati, R, Goenadi, D.H, Damardjati, D.S, Sunarlim, N, Simanungkalit, R.D.M, Suparyani, D. 1998. Pengembangan Rhizoplus untuk Meningkatkan Produksi, Efisiensi Pemupukan Menunjang Keberlanjutan Sistem Produksi Kedelai. Balai Penelitian Bioteknologi Tanaman Pangan.

Sebayang, K., Sihombing, D.A. 1987. The technology impact on soybean yield in Indonesia. In Bottema JWT, Dauphin F, Gijsbers G (Eds.). Soybean Research and Development in Indonesia. Bogor: CGPRT Centre.

Simanungkalit, R.D.M., Suriadikarta, D.A., Saraswati, R., Setyorini D., Hartatik W. 2006. Pupuk Organik dan Pupuk Hayati. Bogor: Balai Besar Litbang Sumberdaya Lahan Pertanian Badan Penelitian dan Pengembangan Pertanian.

Simanungkalit, R.D.M., Saraswati, R. 1993. Application of biotechnology on biofertilizer production in Indonesia. In Manuwoto $\mathrm{S}$, Sularso S, Syamsu K (Eds.). Proc. Seminar on Biotechnology: Sustainable Agriculture and Alternative Solution for Food Crisis. Bogor: PAU-Bioteknologi IPB.

[SQI] Soil Quality Institute. 2001. Guidelines for Soil Quality Assessment in Conservation Planning. Soil Quality Institute. Natural Resources Conservation Services. USDA.

Suwardjo, H., Abdurachman, A., Abujamin, S. 1989. The use of mulch to minimize tillage frequency. Penerbit. Penel. Tanah dan Pupuk 31-37.

Utomo. M. 1995. Kekerasan tanah dan serapan hara tanaman jagung pada olah tanah konservasi jangka panjang. J. Tanah Trop. 1:1-7. 